\title{
The potential use of activated carbon prepared from Ziziphus species for removing dyes from waste waters
}

\author{
Abdelmajid Regti $^{1}$ My Rachid Laamari ${ }^{1} \cdot$ Salah-Eddine Stiriba $^{2,3}$. \\ Mohammadine El Haddad ${ }^{1}$
}

Received: 16 February 2016/Accepted: 24 April 2017/Published online: 3 May 2017

(C) The Author(s) 2017. This article is an open access publication

\begin{abstract}
In this study, the adsorption potential of activated carbon prepared from Ziziphus mauritiana nuts for the removal of methylene blue (MB) from aqueous solution has been investigated using batch mode experiments. The effects of some operating parameters on the removal dye such as, initial pH (2-12), temperature (298-328 K), initial MB concentration $\left(20-100 \mathrm{mg} \mathrm{L}^{-1}\right)$, and contact time (5-70 $\mathrm{min})$ were investigated. Adsorption kinetic showed that the rate adsorption followed the pseudo-second-order kinetic model. Four adsorption isotherms models were applied to experimental equilibrium data (Langmuir, Freundlich, Redlich-Peterson, and Fritz-Schlunder) and the different constants were calculated using non-linear equations models. Fritz-Schlunder model was found the best one to describe the adsorption process which suggests that the adsorption of MB onto activated carbon derived from Ziziphus mauritiana is heterogeneous with a multilayer. Thermodynamic adsorption showed that the process was endothermic and spontaneous in nature.
\end{abstract}

Keywords Activated carbon - Ziziphus mauritiana . Adsorption $\cdot$ Removal dye $\cdot$ Kinetic and thermodynamic study

Mohammadine El Haddad

elhaddad71@gmail.com

1 Equipe de Chimie Analytique et Environnement, Faculté Poly-Disciplinaire, Université Cadi Ayyad, BP 4162, 46000 Safi, Morocco

2 Equipe de Chimie Moléculaire, Matériaux et Modélisation, Faculté Poly-disciplinaire, Université Cadi Ayyad, BP 4162, 46000 Safi, Morocco

3 Instituto de Ciencia Molecular/ICMol, Universidad de Valencia, C/. Catedrático José Beltrán, 2, 46980 Paterna, Valencia, Spain

\section{Introduction}

Dyes are considered as major contaminant of waste water quality. In this fact, dyes effluents contain about $50 \mathrm{mg} \mathrm{L}^{-1}$, and consequently, this concentration is unacceptable. Importantly, the accumulation of dyes in water can seriously damage food chains of humans and animals (Rodrigues da Silva et al. 2012). Most of these dyes are toxic, mutagenic, or carcinogenic (Punzi et al. 2015). Methylene blue (MB) is a cationic dye having various applications in chemistry, biology, medical science, and dyeing industries. Its long-term exposure can cause vomiting, nausea, anemia, and hypertension (Pathania et al. 2013). Therefore, the removal of dyes from wastewaters is required before discharge into receiving waters to avoid these complications.

The wide and general applicable dyes treatment techniques are flocculation, coagulation, precipitation, membrane filtration, electrochemical techniques, ozonation, biological techniques, photodegradation, and advanced oxidative process (Gupta and Suhas 2009; Downham and Collins 2000). These methods are not very successfully due to suffering from many restrictions (Sulak et al. 2007). Adsorption (Al-Qodah and Shawabkah 2009; Al-Qodah et al. 2007) is one of the most popular and extensively used methods for the removal of various dyes from wastewaters. Activated carbons are carbonaceous materials that can be distinguished from elemental carbon by the oxidation of the carbon atoms found on the outer and inner surfaces (Mattson and Mark 1971). These materials are characterized by their extraordinary large specific surface areas, well-developed porosity, and tunable surface containing functional groups (Baker et al. 1992; Jiang et al. 2003). For these reasons, activated carbons are widely used as adsorbents for the removal of organic chemicals and metal ions 
of environmental or economic concern from air, gases, potable water, and wastewater (El-Hendawy 2003). Activated carbon usually increases the cost of the treatment process. Its economical drawback has stimulated the interest to utilize cheaper raw materials for the production of activated carbon (Rengarag et al. 2002; Yahya et al. 2015). Therefore, there is an increasing interest in the development and application of activated carbon derived from several materials. Several studies have been reported to find low-cost carbonaceous materials. Ultimately, Jerusalem artichoke (Yu and Luo 2014), waste rice hulls (Luna et al. 2013), homemade cocoa shell (Ribas et al. 2014), waste tea (Auta and Hameed 2011), coir pith (Santhy and Selvapathy 2006), orange peels (Fernandez et al. 2014), jute sticks (Asadullah et al. 2010), olive stones (Rodriguez-Reinoso et al. 2001; Lafi. 2001; Elsheikh et al. 2003), sugarcane bagasse (Ahmedna et al. 2000), pecan shells (Shawabkeh et al. 1998), and palm seed (Rengarag et al. 2002). The choice of Ziziphus nuts as source of adsorbent is dictated by the fact that it is abundant in several regions, cheap, and especially for a valuation of said biomaterial. The Ziziphus lotus belongs to the family Rhamnaceae (Maraghni et al. 2010). Its fruits used as edible food and traditional Chinese medicine (Adeli and Samavati 2015), claimed to purify the blood and aid digestion (Tripathi et al. 2001).

In the current study, effects of many variables, including $\mathrm{pH}$, adsorbent dosage, contact time, and initial dye concentration, were investigated. In addition, we have achieved the kinetics, thermodynamics, and isotherms models of methylene blue adsorption onto activated carbon derived from Ziziphus mauritiana. The request adsorbent was prepared and characterized by technical spectroscopy such FT-IR, XRD, and by the analysis of SEM.

\section{Materials and methods}

\section{Adsorbent and dye}

The Z. mauritiana nuts were collected, washed with distilled water, and dried at room temperature. The unmodified $Z$. mauritiana nuts were abbreviated as ZMN. The carbonization of ZMN materiel was carried out using an appropriate weight of ZMN and $25 \mathrm{~mL}$ of concentrated $\mathrm{KOH}$ with a mass ratio (1:4) in a glass beaker of $100 \mathrm{~mL}$, heated at $500{ }^{\circ} \mathrm{C}$ for $1 \mathrm{~h}$ producing a black carbonaceous residue. Carbonization removes the volatile matter in the used wastes, whereas activation with chemical agents $\mathrm{KOH}$ would produce a well-developed porosity of activated carbon. The resulting support was neutralized with $\mathrm{HCl} 0.1 \mathrm{~N}$ at neutral $\mathrm{pH}$. After, the carbonized $\mathrm{Z}$. mauritiana nuts

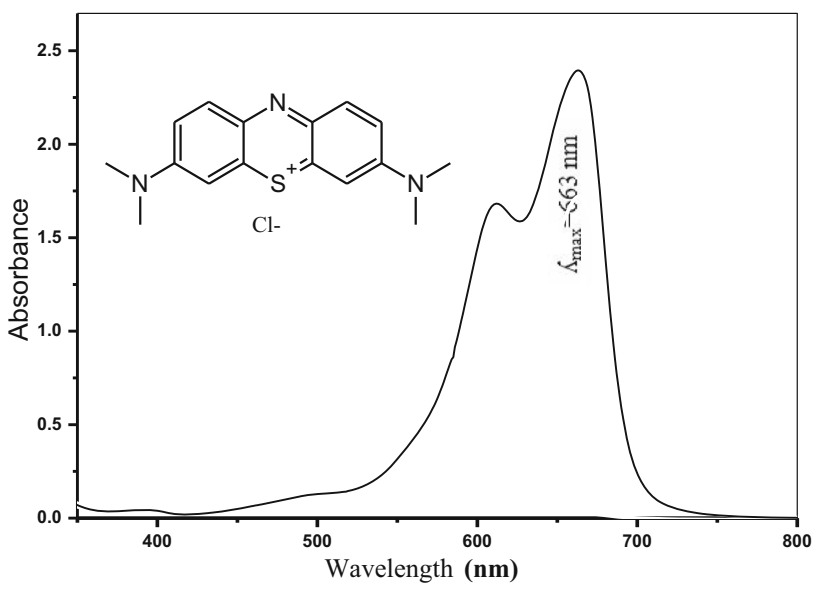

Fig. 1 Molecular formula and UV-Visible spectrum of methylene blue

(denominated as C-ZMN) were filtered and washed several times with distilled water. The C-ZMN adsorbent was then dried at $100{ }^{\circ} \mathrm{C}$ for $2 \mathrm{~h}$ and kept in desiccators for further use.

The cationic dye chosen in this study is methylene blue (MB). This choice is in the basis that MB as a reference adsorbate, being employed in several industrial fields, and used for the adsorption experiments. The molecular formula and UV-visible spectrum of methylene blue are shown in Fig. 1.

\section{Adsorption experiments}

Adsorption experiments were conducted in $50 \mathrm{~mL}$ Erlenmeyer flasks. They were shaken at $150 \mathrm{rpm}$ for the required time in water bath shaker. The effects of various operating parameters such as adsorbent dose $\left(0.2-1 \mathrm{~g} \mathrm{~L}^{-1}\right)$, initial dye concentration $\left(20-100 \mathrm{mg} \mathrm{L}^{-1}\right)$, contact time (5-70 $\mathrm{min}), \mathrm{pH}(2-12)$, and temperature (298-328 K) were achieved on adsorption of MB dye onto C-ZMN. The residual concentrations of $\mathrm{MB}$ dye after adsorption process were determined by UV-Vis spectrophotometer at $663 \mathrm{~nm}$.

For the adsorption isotherm study (used models: Langmuir, Freundlich, Redlich-Peterson and Fritz-Schlunder), the experimental data obtained were compared and the constants appearing in each equation of those models were determined by non-linear regression analysis using origin 9.1 software.

The amount of adsorption $q_{t}\left(\mathrm{mg} \mathrm{g}^{-1}\right)$ at time $t$ (min) was calculated using the following equation:

$q_{t}=\frac{C_{0}-C_{t}}{m} V$,

where $C_{0}$ and $C_{t}\left(\mathrm{mg} \mathrm{L}^{-1}\right)$ are concentrations of MB dye at the initial and time $t$, respectively, $V$ is the volume of the solution (L), and $m$ is the mass of dye adsorbent $(\mathrm{g})$. 
The amount of adsorption $q_{\mathrm{e}}\left(\mathrm{mg} \mathrm{g}^{-1}\right)$ at equilibrium was calculated using the formula:

$q_{\mathrm{e}}=\frac{C_{0}-C_{\mathrm{e}}}{m} V$,

where $C_{\mathrm{e}}\left(\mathrm{mg} \mathrm{L}^{-1}\right)$ is the liquid concentration of dye at equilibrium and $C_{0}\left(\mathrm{mg} \mathrm{L}^{-1}\right)$ is the initial concentration of the dye in solution.

The MB dye removal percentage (\%) can be calculated as follows:

\%removal $=\frac{C_{0}-C_{\mathrm{e}}}{C_{0}} \times 100$,

where $C_{\mathrm{e}}\left(\mathrm{mg} \mathrm{L}^{-1}\right)$ is the concentration of $\mathrm{MB}$ at equilibrium.

\section{Results and discussion}

\section{Characterization of C-ZMN adsorbent}

To investigate the surface characteristic of C-ZMN adsorbent, FT-IR, XRD, and SEM spectrums were studied. The bands positions shown in FT-IR spectrum as depicted in Fig. 2, are 1125, 1381, 1570, 2915, and $3442 \mathrm{~cm}^{-1}$. In this fact, the wide band at $3442 \mathrm{~cm}^{-1}$ is attributed to $\mathrm{O}-\mathrm{H}$ and $\mathrm{N}-\mathrm{H}$ stretching. The bands at 2915,1570 , and $1381 \mathrm{~cm}^{-1}$ correspond, respectively, to unsymmetrical aliphatic $\mathrm{C}-\mathrm{H}$ stretching, $\mathrm{C}=\mathrm{C}$ stretching of aromatic rings, and aromatic $\mathrm{C}=\mathrm{C}$ stretching vibration. Band at $1125 \mathrm{~cm}^{-1}$ is ascribed to $\mathrm{C}-\mathrm{O}$ stretching in alcohol or ether or hydroxyl group (Pavia et al. 1987). The XRD spectrum of C-ZMN adsorbent which was explored in Fig. 3 presented a typical XRD pattern of an amorphous sample. SEM has been a primary tool for characterizing the surface morphology and fundamental physical properties of the adsorbent surface. It is

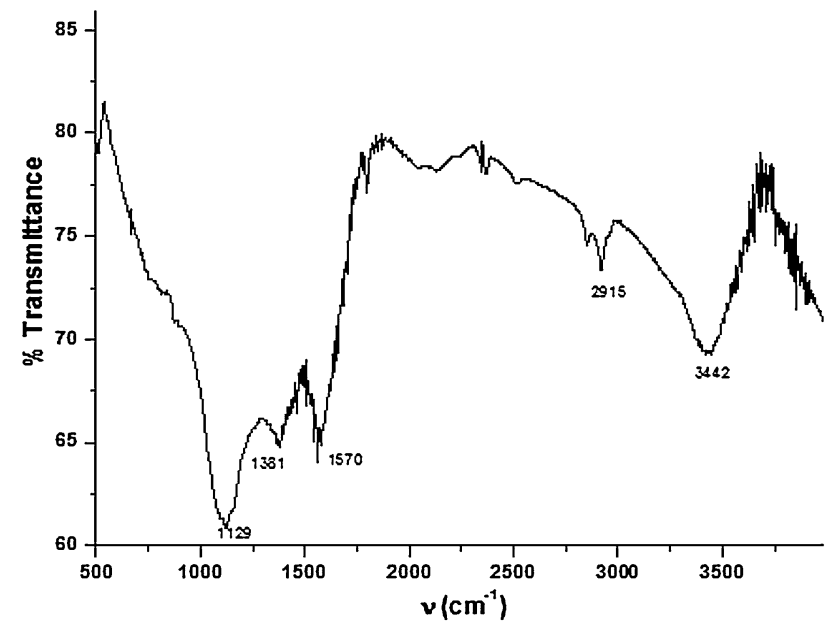

Fig. 2 FT-IR spectrum of C-ZMN adsorbent

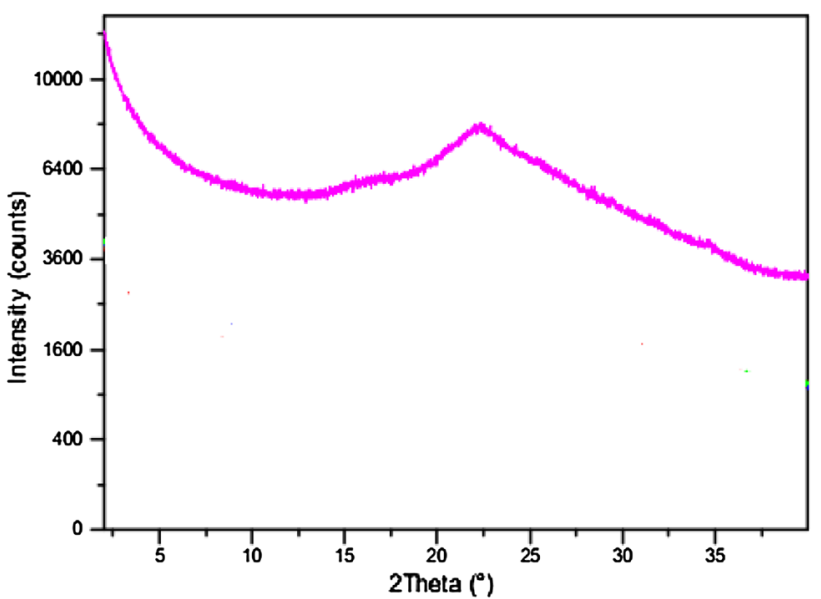

Fig. 3 XRD spectrum of C-ZMN adsorbent

useful for determining the particle shape, porosity, and appropriate size distribution of the adsorbent. The surface morphology of the C-ZMN adsorbent is shown in Fig. 4. The SEM image indicates that the surface is relatively smooth and contains many pores. It shows very distinguished dark spots which can be taken as a sign for effective adsorption of dye molecules in the cavities and pores of this adsorbent.

\section{Effect of C-ZMN dose}

Figure 5 depicts the effect of C-ZMN dose on the removal efficiency of MB from aqueous solutions. In the light of these results, it appeared that at equilibrium time of $70 \mathrm{~min}$, the percent adsorption was increased from 47.16 to $86.5 \%$ when the adsorbent dose increased from 0.2 to $1 \mathrm{~g} \mathrm{~L}^{-1}$. This behavior is done, because that number of available adsorption sites and the surface area increase by increasing the adsorbent dose, it, therefore, results in the

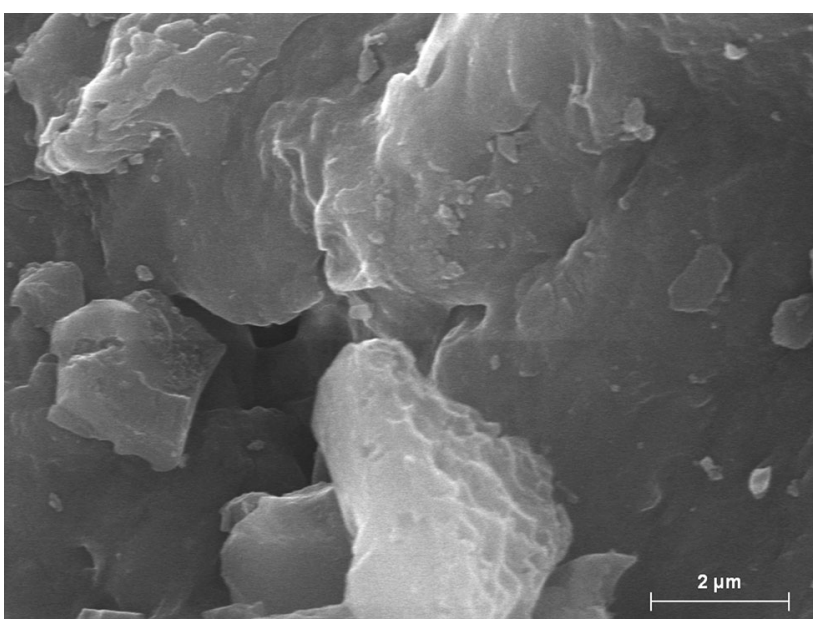

Fig. 4 SEM of C-ZMN adsorbent 


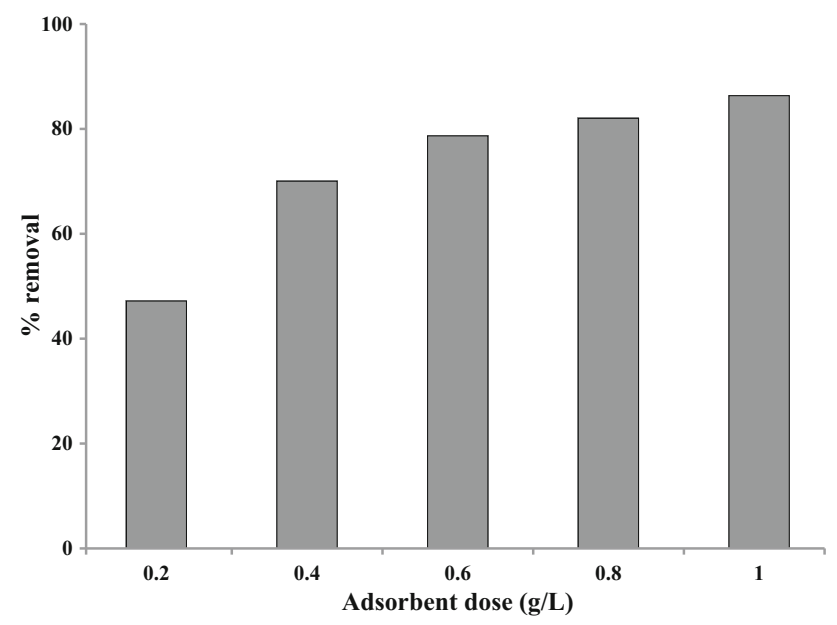

Fig. 5 Effect of C-ZMN dose on the removal of MB. Initial dye concentration: $100 \mathrm{mg} \mathrm{L}^{-1}$; temperature: $298 \mathrm{~K}$

increase of amount of adsorbed dye. It was also observed at equilibrium time a decrease in amount of adsorption. This may be attributed to overlapping or aggregation of adsorption sites resulting in a decrease in total adsorbent surface area available to $\mathrm{MB}$ and as an increase in diffusion path length (El Haddad et al. 2012).

\section{Effect of MB concentration}

The effect of initial MB concentration on the adsorption rate was investigated. The experiment was carried out with fixed C-ZMN dose $\left(0.8 \mathrm{~g} \mathrm{~L}^{-1}\right)$ at room temperature. The adsorption capacity for C-ZMN was increased from 17.86 to $102.5 \mathrm{mg} \mathrm{g}^{-1}$ when the MB concentration was increased from 20 to $100 \mathrm{mg} \mathrm{L}^{-1}$ (see Fig. 6). Maximum adsorption MB dye was attained within $20 \mathrm{~min}$ after the start of every experiment. The Increasing of MB concentration enhances the interaction between the dye and C-ZMN providing necessary driving force to overcome the resistance to mass

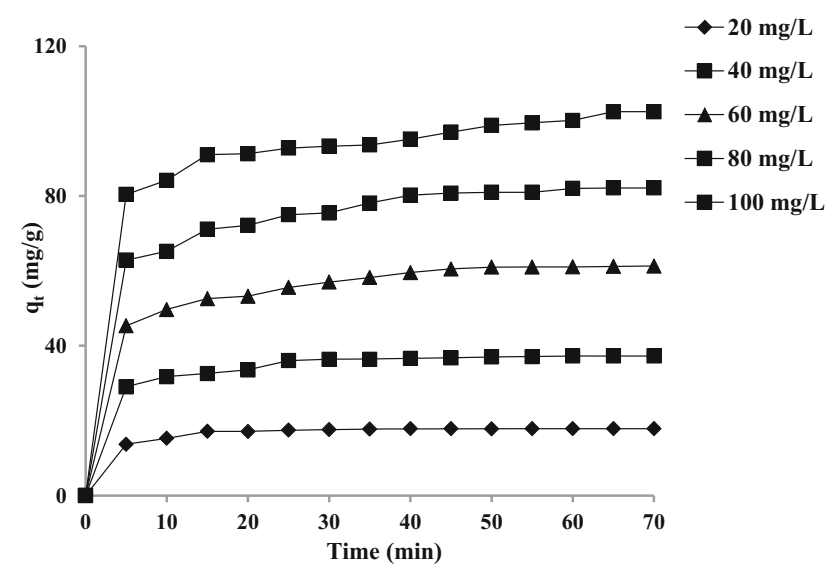

Fig. 6 Effect of the initial MB concentration and contact time on the removal of MB. C-ZMN: $0.8 \mathrm{~g} \mathrm{~L}^{-1}$; temperature: $298 \mathrm{~K}$ transfer of dye (Gil et al. 2011). Therefore, rate of adsorption and hence dye uptake increased with an increase in MB dye concentration.

\section{Effect of pH}

We achieve the accurate study of the adsorption of MB dye onto $\mathrm{C}-\mathrm{ZMN}$ with variation of $\mathrm{pH}$ ranging between $(2$ and 12), and the results are shown in Fig. 7. It is observed that removal \% increases slightly from 19.22 to $88.77 \%$ when $\mathrm{pH}$ was increasing from 2 to 12 . To explain the results, we have determined the point of zero charge $\left(\mathrm{pH}_{\mathrm{PZC}}=2.3\right)$ of C-ZMN, by the titration method (Preethi and Sivasamy 2006). At $\mathrm{pH}>\mathrm{pH}_{\mathrm{PZC}}$, negatively charged adsorbent sites increase, which favor the adsorption of $\mathrm{MB}$ as cationic dye due to attractive electrostatic interactions. The lower adsorption of this dye at $\mathrm{pH}=2\left(\mathrm{pH}<\mathrm{pH}_{\mathrm{PZC}}\right)$ was not solely due to the presence of excess $\mathrm{H}^{+}$ions competing with the dye cation for the adsorption sites, but also to the electrostatic repulsion between the cationic dye MB and protonated C-ZMN surface. The similar result was obtained and reported by other author's researchers (Hameed 2009).

\section{Adsorption kinetic}

Many kinetic models have been proposed to elucidate the mechanism of dye biosorption. The rate and mechanism of biosorption is controlled by various factors like physical and/or chemical properties of biosorbent as well as mass transfer process. These kinetic models are useful for the design and optimization of effluent treatment process. To investigate the mechanism of Methylene blue biosorption by C-ZMN, the following kinetic models were considered. The kinetic models applied in this study are the pseudo-first order (Lagergren 1898) and pseudo-second order (Ho and

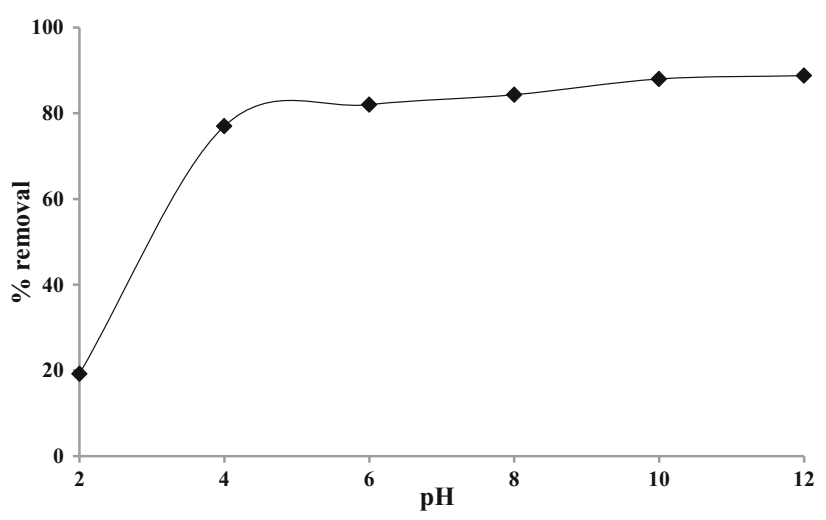

Fig. 7 Effect of $\mathrm{pH}$ on the removal of MB onto C-ZMN. Initial MB concentration: $100 \mathrm{mg} \mathrm{L}^{-1}$; adsorbent amount: $0.8 \mathrm{~g} \mathrm{~L}^{-1}$; agitation time: $70 \mathrm{~min}$; temperature: $298 \mathrm{~K}$ 
McKay 1998). The linearized kinetic used for the pseudofirst order model was as follows:

$\log \left(q_{\mathrm{e}}-q_{t}\right)=\log \left(q_{\mathrm{e}}\right)-\frac{k_{1}}{2.303} t$

where $q_{\mathrm{e}}\left(\mathrm{mg} \mathrm{g}^{-1}\right)$ is the amount of dye adsorbed at equilibrium, $q_{t}\left(\mathrm{mg} \mathrm{g}^{-1}\right)$ is the amount of dye adsorbed at time $t, k_{1}$ is the pseudo-first-order rate constant $\left(\min ^{-1}\right)$, and $t$ is time ( $\mathrm{min}$ ).

The linearized form of the pseudo-second-order kinetic model is presented as follows:

$\frac{t}{q_{t}}=\frac{1}{k_{2} q_{\mathrm{e}}^{2}}+\frac{1}{q_{\mathrm{e}}} t$,

where $k_{2}$ is the pseudo-second-order rate constant (g mg ${ }^{-1} \mathrm{~min}$ ).

The experimental kinetic data have been plotted as $\log$ $\left(q_{\mathrm{e}}-q_{t}\right)$ and $t$ for the pseudo-first order model and as $t / q_{t}$ and $t$ (as shown in Fig. 8) for the pseudo-second-order model. The kinetic parameters related to pseudo-first-order and to pseudo-second-order models were obtained according to the intercept and slope from the plot of $\log \left(q_{\mathrm{e}}-q_{t}\right)$ versus $t$ and $t / q_{t}$ versus $t$, respectively. The applicability of the kinetic model is compared between $r^{2}$ and the calculated $q_{\mathrm{e}}$ (cal) and the experimental $q_{\mathrm{e}}$ (exp) values. The different kinetic parameters are summarized in Table 1 . The $r^{2}$ values of the pseudo-second-order kinetic model are higher than those of pseudo-first order kinetic model. Meanwhile, the $q_{\mathrm{e}}$ (cal) values calculated by the pseudo-second-order kinetic model are much closer to the $q_{\mathrm{e}}$ (exp) values than fitting by pseudo-first-order kinetic model. Therefore, the pseudo-second-order kinetic model is more appropriate to describe the adsorption behavior of MB onto C-ZMN.

Intraparticle diffusion model was employed to identify the mechanism by plotting the uptake

$\mathrm{q}_{\mathrm{t}}$ versus the square root of time $t^{1 / 2}$ using the mathematical expression:

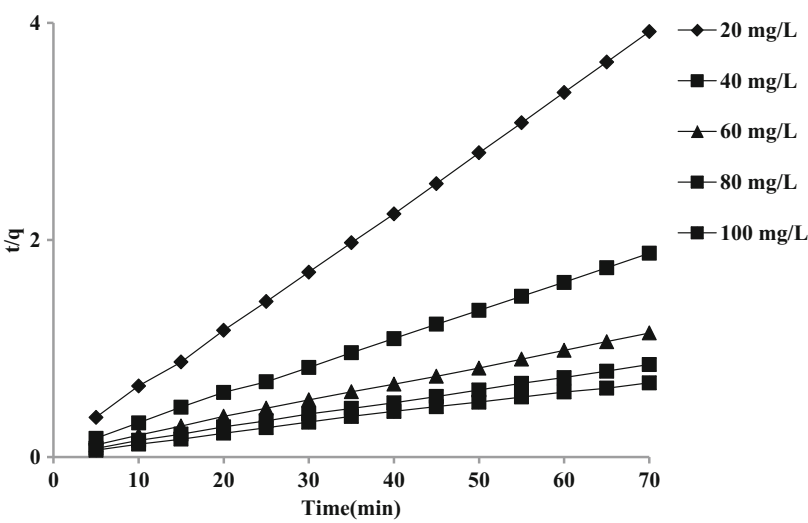

Fig. 8 Plot of linear pseudo-second-order kinetic model at different MB concentrations. C-ZMN adsorbent: $0.8 \mathrm{~g} / 50 \mathrm{~mL}$; temperature $298 \mathrm{~K}$ $q_{t}=k_{\mathrm{id}} t^{1 / 2}+C$

If the plot is linear with the line passing through the origin, then intra particle diffusion is the rate controlling step (Bhattacharyya and Sharma 2004). The constants in the intraparticle diffusion model $K_{\mathrm{id}}$ and $C$ were evaluated from the plot, and some results are depicted in Table 1 . The correlation coefficients for the model are low, which indicates that the intraparticle diffusion is not a rate determining step for the biosorption process of MB onto $\mathrm{C}-\mathrm{ZMN}$. These results confirmed that the actual adsorption contains surface adsorption.

\section{Adsorption isotherm}

Adsorption isotherms are basic requirements for the design of adsorption systems. To describe the removal mechanism of $\mathrm{MB}$ from aqueous media onto $\mathrm{C}-\mathrm{ZMN}$, four isotherm models (Langmuir, Freundlich, Redlich-Peterson, and Fritz-Schlunder) were applied. The Langmuir model (1916) is based on monolayer adsorption onto a homogeneous structure without any reaction between the adsorbed molecules. This model is illustrated as:

$q_{\mathrm{e}}=\frac{K_{\mathrm{L}} q_{\mathrm{m}} C_{\mathrm{e}}}{1+K_{\mathrm{L}} C_{\mathrm{e}}}$

where $q_{\mathrm{m}}\left(\mathrm{mg} \mathrm{g}^{-1}\right)$ is the maximum adsorption capacity, $q_{\mathrm{e}}$ is the amount of $\mathrm{MB}$ in the $\mathrm{C}-\mathrm{ZMN}$ at equilibrium $\left(\mathrm{mg} \mathrm{g}^{-1}\right), C_{\mathrm{e}}$ is the equilibrium concentration $\left(\mathrm{mg} \mathrm{L}^{-1}\right)$, and $K_{\mathrm{L}}\left(\mathrm{L} \mathrm{mg}^{-1}\right)$ is Langmuir constant related to adsorption capacity and rate of adsorption. The essential characteristics of Langmuir equation can be expressed in terms of dimensionless separation factor, $R_{\mathrm{L}}$, defined as:

$R_{\mathrm{L}}=\frac{1}{1+K_{\mathrm{L}} C_{0}}$,

where $C_{0}$ is the initial concentration of $\mathrm{MB}$ dye; the $R_{\mathrm{L}}$ value implies whether the adsorption is: unfavorable: $R_{\mathrm{L}}>1$, linear: $R_{\mathrm{L}}=1$, favorable: $0<R_{\mathrm{L}}<1$, irreversible: $R_{\mathrm{L}}=0$.

The Freundlich isotherm (1906) can be applied to nonideal adsorption on heterogeneous surfaces as well as multilayer adsorption. It is expressed by the following equation:

$q_{\mathrm{e}}=k_{\mathrm{F}} C_{\mathrm{e}}^{\frac{1}{n}}$

where $k_{\mathrm{F}}\left(\mathrm{mg} \mathrm{g}^{-1}\right)$ and $n$ are Freundlich constants related to the capacity of adsorption and favorability of adsorption, respectively. The values in the range of $0<n<10$ indicate that adsorption is favorable. The greater the value of $n$, better is the favorability of the adsorption.

The Redlich-Peterson isotherm (1959) is a combination of Langmuir-Freundlich model. It approaches the Freundlich model at high concentration and is in accord with 
Table 1 Kinetic parameters of pseudo-first-order, pseudo-second-order, and intraparticle models for MB removal using C-ZMN

\begin{tabular}{|c|c|c|c|c|c|c|c|c|c|c|}
\hline \multirow{2}{*}{$\begin{array}{l}\mathrm{MB} \\
\left(\mathrm{mg} \mathrm{L}^{-1}\right)\end{array}$} & \multicolumn{4}{|c|}{ Pseudo-first-order } & \multicolumn{3}{|c|}{ Pseudo-second-order } & \multicolumn{3}{|c|}{ Intraparticle diffusion model } \\
\hline & $\begin{array}{l}k_{1} \\
\left(\min ^{-1}\right)\end{array}$ & $\begin{array}{l}q_{\mathrm{e}}(\mathrm{cal}) \\
\left(\mathrm{mg} \mathrm{g}^{-1}\right)\end{array}$ & $\begin{array}{l}q_{\mathrm{e}}(\exp ) \\
\left(\mathrm{mg} \mathrm{g}^{-1}\right)\end{array}$ & $r^{2}$ & $\begin{array}{l}k_{2} \times 10^{-3} \\
\left(\mathrm{~g} \mathrm{mg}^{-1} \mathrm{~min}\right)\end{array}$ & $\begin{array}{l}q_{\mathrm{e}}(\mathrm{cal}) \\
\left(\mathrm{mg} \mathrm{g}^{-1}\right)\end{array}$ & $r^{2}$ & $\begin{array}{l}k_{\text {id }} \\
\left(\mathrm{mg} \mathrm{g}^{-1} \mathrm{~min}\right)\end{array}$ & $C$ & $r^{2}$ \\
\hline 20 & 0.127 & 9.48 & 17.86 & 0.97 & 39 & 18.52 & 0.999 & 0.531 & 14.1 & 0.673 \\
\hline 40 & 0.086 & 17.3 & 37.28 & 0.938 & 12 & 38.46 & 0.999 & 1.259 & 28 & 0.853 \\
\hline 60 & 0.085 & 40.18 & 61.27 & 0.932 & 4.5 & 66.66 & 0.999 & 2.574 & 41.9 & 0.937 \\
\hline 80 & 0.074 & 44.05 & 82.15 & 0.942 & 3.3 & 90.9 & 0.999 & 3.278 & 57.21 & 0.941 \\
\hline 100 & 0.046 & 38.02 & 102.5 & 0.787 & 2.9 & 111.12 & 0.998 & 3.343 & 74.91 & 0.959 \\
\hline
\end{tabular}

the low concentration limit of the Langmuir equation. The equation is given as:

$q_{\mathrm{e}}=\frac{K_{\mathrm{R}} C_{\mathrm{e} e}}{1+\alpha_{\mathrm{R}} C_{\mathrm{e}}^{\beta}}$,

where $K_{\mathrm{R}}$ is Redlich-Peterson isotherm constant $\left(\mathrm{L} \mathrm{g}^{-1}\right)$, $\alpha_{\mathrm{R}}$ is Redlich-Peterson isotherm constant $\left(\mathrm{L} \mathrm{mg}^{-1}\right)$, and $\beta$ is the exponent which lies between 0 and 1 . The constant $\beta$ can characterize the isotherm as: if $\beta=1$, the Langmuir will be the preferable isotherm, while if $\beta=0$, the Freundlich isotherm will be the preferable isotherm.

The equations of Langmuir and Freundlich were also developed empirically by Fritz and Schlunder (1974). It is expressed by the equation:

$q_{\mathrm{e}}=\frac{A C_{\mathrm{e}}^{\alpha}}{1+B C_{\mathrm{e}}^{\beta}}$,

where $q_{\mathrm{e}}\left(\mathrm{mg} \mathrm{g}^{-1}\right)$ is the adsorbed amount of $\mathrm{MB}$ at equilibrium, $C_{\mathrm{e}}$ is the equilibrium concentration of $\mathrm{MB}$ (mg L ${ }^{-1}$ ), constants $A$ and $B$ are the Fritz-Schlunder parameters, and $\alpha$ and $\beta$ are the Fritz-Schlunder equation exponents.

The sum of absolute errors is expressed by the equation:

$\mathrm{SAE}=\sum_{i=1}^{n}\left|q_{\mathrm{e}(\mathrm{cal})}-q_{\mathrm{e}(\mathrm{exp})}\right|$.

To confirm the best model for the adsorption system, it is necessary to analyze the data using errors analysis like sum of the absolute errors (SAE) combined with the values of determined correlation coefficient $r^{2}$.

The results of these analyses are tabulated in Table 2. The amounts of adsorbed quantities of dye at the equilibrium $q_{\mathrm{e}}$ versus $C_{\mathrm{e}}$ are drawn in Fig. 9. The best fit of experimental data was obtained with the Fritz-Schlunder model with greatest $r^{2}$ value and smallest SAE values.

Figure 10 depicts the plot of the calculated $R_{\mathrm{L}}$ values versus the initial dye concentration at 298, 308, 318, and $328 \mathrm{~K}$. It was observed that all the $R_{\mathrm{L}}$ values obtained were between 0 and 1 , showing that the adsorption of MB onto C-ZMN was favorable. The $R_{\mathrm{L}}$ values decrease with increase in initial dye concentration, indicating that the
Table 2 Adsorption isotherm constants for MB removal onto C-ZMN

\begin{tabular}{|c|c|c|c|c|}
\hline & \multicolumn{4}{|l|}{ Temperature } \\
\hline & $298 \mathrm{~K}$ & $308 \mathrm{~K}$ & $318 \mathrm{~K}$ & $328 \mathrm{~K}$ \\
\hline \multicolumn{5}{|c|}{ Langmuir isotherm } \\
\hline$q_{\mathrm{m}}\left(\mathrm{mg} \mathrm{g}^{-1}\right)$ & 152.89 & 158.12 & 178 & 153.22 \\
\hline$K_{\mathrm{L}}\left(\mathrm{L} \mathrm{mg}^{-1}\right)$ & 0.123 & 0.135 & 0.139 & 0.219 \\
\hline$r^{2}$ & 0.79 & 0.8 & 0.82 & 0.84 \\
\hline SAE & 47.77 & 51.76 & 54.95 & 51.42 \\
\hline \multicolumn{5}{|c|}{ Freundlich isotherm } \\
\hline$K_{\mathrm{F}}\left(\mathrm{mg} \mathrm{g}^{-1}\right)$ & 24.54 & 27.25 & 27.68 & 35.5 \\
\hline$n$ & 1.96 & 1.97 & 1.796 & 2.18 \\
\hline$r^{2}$ & 0.76 & 0.75 & 0.78 & 0.75 \\
\hline SAE & 57.36 & 62.06 & 63.45 & 65.88 \\
\hline \multicolumn{5}{|c|}{ Fritz-Schlunder isotherm } \\
\hline$A$ & $7.81 \times 10^{-12}$ & $3.19 \times 10^{-6}$ & $7.6 \times 10^{-3}$ & 1.435 \\
\hline$B$ & $1.56 \times 10^{-13}$ & $5.79 \times 10^{-8}$ & $1.29 \times 10^{-4}$ & 0.02 \\
\hline$\alpha$ & 24.92 & 15.8 & 9.48 & 5.66 \\
\hline$\beta$ & 24.68 & 15.57 & 9.24 & 5.49 \\
\hline$r^{2}$ & 0.999 & 0.996 & 0.962 & 0.97 \\
\hline SAE & 3.17 & 6.52 & 22.69 & 21.45 \\
\hline \multicolumn{5}{|c|}{ Redlich-Peterson isotherm } \\
\hline$K_{\mathrm{R}}\left(\mathrm{L} \mathrm{g}^{-1}\right)$ & 14.1 & 15.59 & 17.27 & 21.27 \\
\hline$\alpha_{\mathrm{R}}\left(\mathrm{L} \mathrm{mg}^{-1}\right)$ & 0.012 & 0.056 & 0.003 & 0.021 \\
\hline$\beta$ & 1.667 & 2.13 & 2.286 & 2.565 \\
\hline$r^{2}$ & 0.81 & 0.83 & 0.85 & 0.83 \\
\hline SAE & 44.81 & 42.76 & 42.45 & 34.11 \\
\hline
\end{tabular}

adsorption was more favorable at higher MB concentration. Adsorption capacity increases with the increasing temperature and the higher value of adsorption capacity attained $108.97 \mathrm{mg} \mathrm{g}^{-1}$ at $328 \mathrm{~K}$. The values of $K_{\mathrm{L}}$ increased with increase in temperature, indicating that increasing temperature induced a higher maximum adsorption capacity.

\section{Thermodynamic adsorption}

The thermodynamic parameters were evaluated to confirm the nature of the adsorption and the inherent energetic 

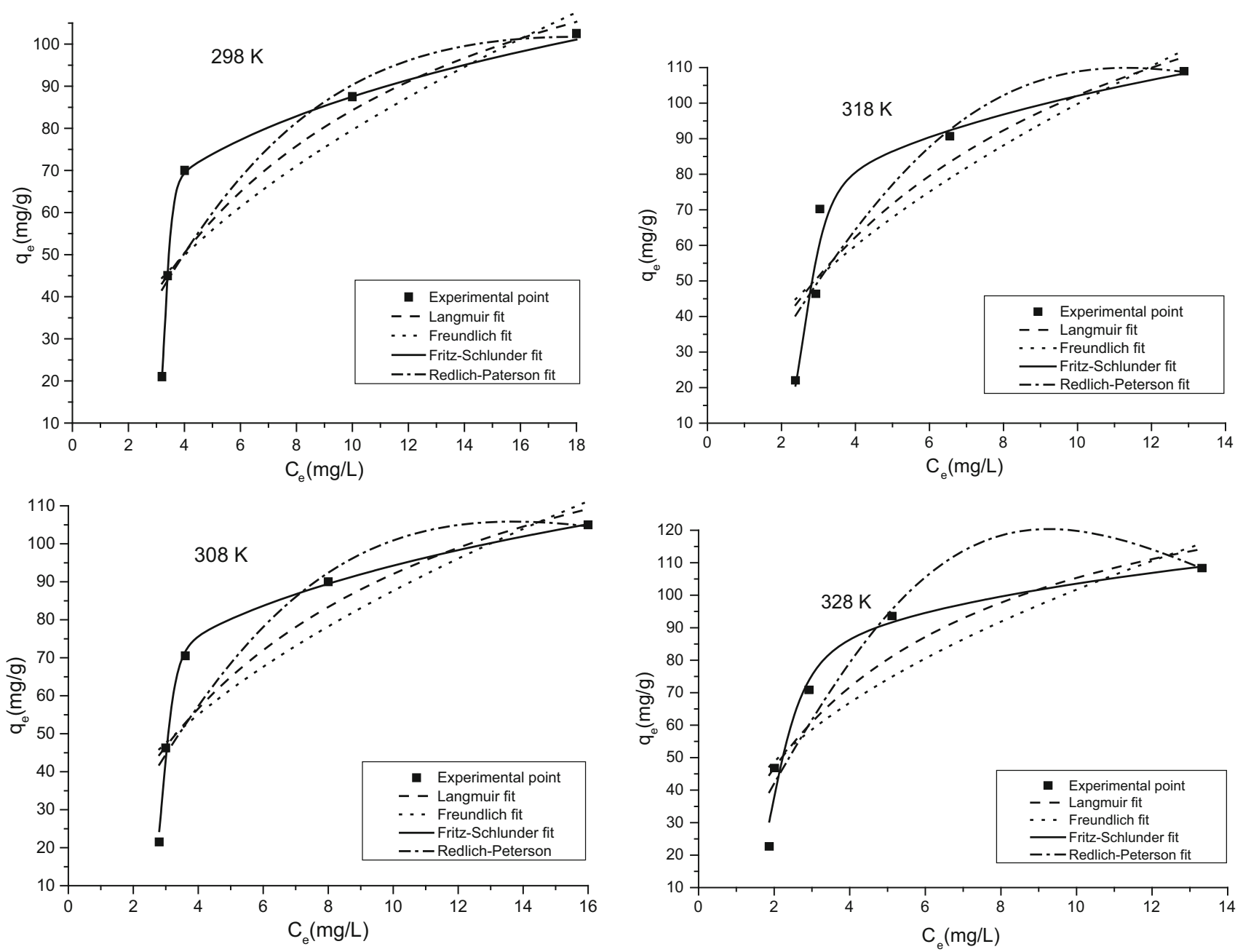

Fig. 9 Experimental points and non-linear fitted curves from isotherm

changes involved during MB adsorption. Standard enthalpy $\left(\Delta H^{\circ}\right)$, free energy $\left(\Delta G^{\circ}\right)$, and entropy change $\left(\Delta S^{\circ}\right)$ were calculated to determine the thermodynamic feasibility and the spontaneous nature of the process (Choi et al. 2009). by:

The free energy change of the sorption reaction is given

$\Delta G^{\circ}=-\mathrm{RT} \ln \left(K_{\mathrm{C}}\right)$,

where $\Delta G^{\circ}$ is the free energy change $\left(\mathrm{kJ} \mathrm{mol}^{-1}\right), R$ is the universal gas constant $\left(8.314 \mathrm{~J} \mathrm{~mol}^{-1} \mathrm{~K}\right), T$ is the absolute temperature $(\mathrm{K})$, and $K_{\mathrm{C}}$ states the equilibrium constants $\left(q_{\mathrm{e}} / C_{\mathrm{e}}\right)$. The values of $\Delta H^{\circ}$ and $\Delta S^{\circ}$ can be calculated from the Van't Hoff equation:

$\ln \left(K_{\mathrm{C}}\right)=-\frac{\Delta H^{\circ}}{\mathrm{RT}}+\frac{\Delta S^{\circ}}{R}$,

where $K_{\mathrm{C}}$ is plotted against $1 / T$; a straight line with the slope $\left(-\Delta H^{\circ} / R\right)$ and intercept $\left(\Delta S^{\circ} / R\right)$ are found, as shown in Fig. 11. The calculated thermodynamic parameters are depicted in Table 3. The values of $\Delta H^{\circ}$ are within the

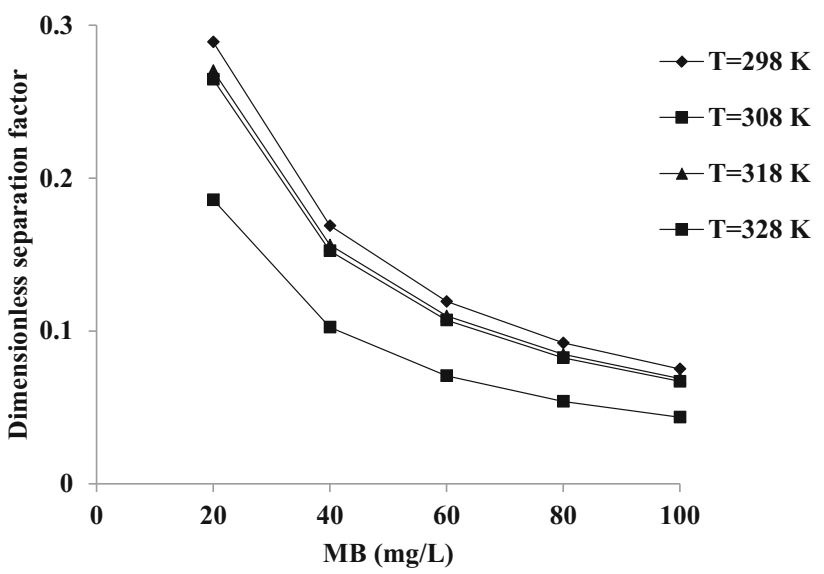

Fig. 10 Dimensionless separation factor, $R_{\mathrm{L}}$, versus MB concentration

range of (1-93 kJ mol$\left.{ }^{-1}\right)$ indicating the physisorption. From these results, it is clear that physisorption is much more favorable for the adsorption of MB. 


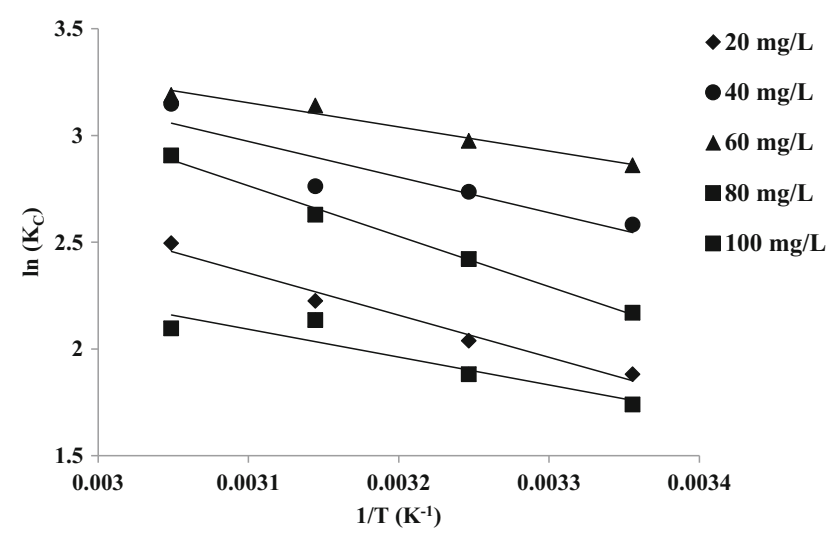

Fig. 11 Plots of $\operatorname{Ln} K_{\mathrm{C}}$ against $1 / T$

Table 3 Thermodynamic parameters of MB adsorption onto C-ZMN

\begin{tabular}{llllll}
\hline $\mathrm{MB}\left(\mathrm{mg} \mathrm{L}^{-1}\right)$ & 20 & 40 & 60 & 80 & 100 \\
$\Delta G^{\circ}\left(\mathrm{kJ} \mathrm{mol}^{-1}\right)$ & & & & & \\
$298 \mathrm{~K}$ & -4.66 & -6.39 & -7.06 & -5.37 & -4.31 \\
$308 \mathrm{~K}$ & -5.22 & -7.03 & -7.60 & -6.19 & -4.81 \\
$318 \mathrm{~K}$ & -5.88 & -7.29 & -8.30 & -6.92 & -5.63 \\
$328 \mathrm{~K}$ & -6.81 & -8.56 & -8.69 & -7.92 & -5.69 \\
$\Delta H^{\circ}\left(\mathrm{kJ} \mathrm{mol}^{-1}\right)$ & 16.39 & 13.68 & 9.4 & 19.62 & 10.84 \\
$\Delta S^{\circ}(\mathrm{J} \mathrm{mol}$
\end{tabular}

Table 4 Comparison of adsorption capacities of various adsorbents for $\mathrm{MB}$

\begin{tabular}{|c|c|c|c|}
\hline Adsorbent & Treatment & $\begin{array}{l}q_{\mathrm{m}} \\
\left(\mathrm{mg} \mathrm{g}^{-1}\right)\end{array}$ & References \\
\hline Sugarcane dust & No treatment & 3.745 & $\begin{array}{l}\text { Khattri and Singh } \\
\text { (1999) }\end{array}$ \\
\hline Orange peel & No treatment & 18.60 & $\begin{array}{l}\text { Annadurai et al. } \\
\text { (2002) }\end{array}$ \\
\hline Banana pith & No treatment & 20.80 & $\begin{array}{l}\text { Annadurai et al. } \\
\text { (2002) }\end{array}$ \\
\hline $\begin{array}{l}\text { Moroccan } \\
\text { Wood }\end{array}$ & No treatment & 22.12 & Regti et al. (2014) \\
\hline Hazelnut shell & No treatment & 76.90 & Ferrero (2007) \\
\hline $\begin{array}{l}\text { Casuarina } \\
\text { needle }\end{array}$ & No treatment & 110.8 & Dahri et al. (2015) \\
\hline diatomite & $\begin{array}{c}\text { Acid/thermal } \\
\text { treatment }\end{array}$ & 87 & Al-Qodah (1998) \\
\hline $\begin{array}{l}\text { Silk cotton } \\
\text { carbon }\end{array}$ & $\begin{array}{l}\text { Acid/thermal } \\
\text { treatment }\end{array}$ & 120 & $\begin{array}{l}\text { Kadirvelu et al. } \\
\text { (2003) }\end{array}$ \\
\hline $\begin{array}{l}\text { Pistachio shells } \\
\text { carbon }\end{array}$ & $\begin{array}{c}\text { Acid/thermal } \\
\text { treatment }\end{array}$ & 129 & Attia et al. (2003) \\
\hline $\begin{array}{l}\text { Bamboo dust } \\
\text { carbon }\end{array}$ & $\begin{array}{c}\text { Acid/thermal } \\
\text { treatment }\end{array}$ & 143.20 & $\begin{array}{l}\text { Kannan and } \\
\quad \text { Sundaram (2001) }\end{array}$ \\
\hline $\mathrm{C}-\mathrm{ZMN}$ & $\begin{array}{c}\mathrm{KOH} / \text { thermal } \\
\text { treatment }\end{array}$ & 152.89 & The present work \\
\hline
\end{tabular}

The positive values of $\Delta H^{\circ}$ show the endothermic nature of adsorption and it governs the possibility of physical adsorption (Karagoz et al. 2008). The negative values of $\Delta G^{\circ}$ show that the adsorption is highly favorable and spontaneous. The positive value of $\Delta S^{\circ}$ shows the increased randomness with $\mathrm{MB}$ adsorption, probably because the number of desorbed water molecules is larger than that of adsorbed MB molecules.

\section{Comparison of adsorption capacities of C-ZMN with those of various adsorbents}

The maximum adsorption capacities of various adsorbents prepared differently used for MB removal were compared with the present study and given in Table 4. From Table 4, the capacities of adsorbents for adsorbing MB are in a wide range; it is vary from 3.745 to $152.89 \mathrm{mg} \mathrm{g}^{-1}$. It's appeared that C-ZMN can be considered as a good adsorbent with an adsorption capacity of $152.89 \mathrm{mg} \mathrm{g}^{-1}$.

\section{Conclusions}

This paper demonstrates that C-ZMN was an effective adsorbent for removal of MB from aqueous solution. The experimental factors such as adsorbent dose, contact time, dye concentrations, adsorption kinetic, and isotherm models were investigated to study the adsorption process. MB followed the pseudo-second model well. The equilibrium isotherm analysis reflects that the Fritz-Schlunder model well-fitted isotherm data. Furthermore, thermodynamic studies show that this adsorption process was spontaneous, favorable, and endothermic. Therefore, it can be concluded that the C-ZMN was a promising adsorbent.

Open Access This article is distributed under the terms of the Creative Commons Attribution 4.0 International License (http:// creativecommons.org/licenses/by/4.0/), which permits unrestricted use, distribution, and reproduction in any medium, provided you give appropriate credit to the original author(s) and the source, provide a link to the Creative Commons license, and indicate if changes were made.

\section{References}

Adeli M, Samavati V (2015) Studies on the steady shear fow behavior and chemical properties of water-soluble polysaccharide from ziziphus. Int J Biol Macromol 72:580-587

Ahmedna M, Marshall WE, Rao RM (2000) Production of granular activated carbons from select agricultural by products and evaluation of their physical, chemical, and adsorptive properties. Bioresour Technol 71:113-123

Al-Qodah Z (1998) Adsorption of methylene blue with diatomite. J Eng Technol 17:128-137 
Al-Qodah Z, Shawabkah R (2009) Production and characterization of granular activated carbon from activated. Braz J Chem Eng 26:127-136

Al-Qodah Z, Lafi WK, Al-Anber Z, Al-Shannag M, Harahsheh A (2007) Adsorption of methylene blue by acid and heat treated diatomaceous silica. Desalination 217:212-224

Annadurai G, Juang RS, Lee DJ (2002) Use of cellulose based wastes for adsorption of dyes from aqueous solutions. J Hazard Mater 92:263-274

Asadullah M, Asaduzzaman M, Kabir MS, Mostofa MG, Miyazawa T (2010) Chemical and structural evaluation of activated carbon prepared from jute sticks for Brilliant Green dye removal from aqueous solution. J Hazard Mater 174:437-443

Attia AA, Girgis BS, Khedr S (2003) Capacity of activated carbon derived from pistachio shells by $\mathrm{H}_{3} \mathrm{PO}_{4}$ in the removal of dyes and phenolics. J Chem Technol Biotechnol 78:611-619

Auta M, Hameed BH (2011) Optimized waste tea activated carbon for adsorption of methylene blue and acid blue 29 dyes using response surface methodology. Chem Eng J 175:233-243

Baker FS, Miller CE, Repic AJ, Tolles ED (1992) Activated carbon. Kirk-Othmer Encycl Chem Technol 4:1015-1037

Bhattacharyya KG, Sharma A (2004) Azadirachta indicaleaf powder as an effective biosorbent for dyes: a case study with aqueous congo red solutions. J Environ Manage 71(3):217-229

Choi HD, Jung WS, Cho JM, Ryu BG, Yang JS, Baek K (2009) Adsorption of $\mathrm{Cr}(\mathrm{VI})$ onto cationic surfactant-modified activated carbon. J Hazard Mater 166:642-646

Dahri MK, Kooh MRR, Lim LBL (2015) Application of Casuarina equisetifolia needle for the removal of methylene blue and malachite green dyes from aqueous solution. Alex Eng $\mathrm{J}$ 54:1253-1263

Downham A, Collins P (2000) Coloring our food in the last and next millennium. Int J Food Sci Technol 35:5-22

El Haddad M, Mamouni R, Saffaj N, Lazar S (2012) Removal of a cationic dye-basic red 12-from aqueous solution by adsorption onto animal bone meal. J Assoc Arab Univ Basic Appl Sci 12:48-54

El-Hendawy AA (2003) Influence of $\mathrm{HNO}_{3}$ oxidation on the structured and adsorptive properties of corncob activated carbon. Carbon 41:713-722

Elsheikh A, Newman A, Al-Daffaee H, Phull S, Crosswell N (2003) Characterization of activated carbon prepared from a single cultivar of Jordanian olive stones by chemical and physicochemical techniques. J Anal Appl Pyrol 30:1-16

Fernandez ME, Nunell GV, Bonelli PR, Cukierman AL (2014) Activated carbon developed from orange peels: batch and dynamic competitive adsorption of basic dyes. Ind Crops Prod 62:437-445

Ferrero F (2007) Dye removal by low cost adsorbent: hazelnut shells in comparison with wood sawdust. J Hazard Mater 142:144-152

Freundlich HMF (1906) Über die adsorption in lösungen. Z Phys Chem (Leipzig) 57A:385-470

Fritz W, Schlunder EU (1974) Simultaneous adsorption equilibria of organic solutes in dilute aqueous solution on activated carbon. Chem Eng Sci 29:1279-1282

Gil A, Assis FCC, Albeniz S, Korili SA (2011) Removal of dyes from wastewaters by adsorption on pillared clays. Chem Eng J 168:1032-1040

Gupta VK, Suhas F (2009) Application of low-cost adsorbents for dye removal: a review. J Environ Manag 90:2313-2342

Hameed BH (2009) Removal of cationic dye from aqueous solution using jackfruit peel as non-conventional low-cost sorbent. J Hazard Mater 162:344-350

Ho YS, McKay G (1998) Sorption of dye from aqueous solution by peat. Chem Eng J 70:115-124
Jiang Z, Lin Y, Sun X, Tain F, Sun F, Liang C, You W, Han C, Li C (2003) Activated carbon chemically modified by concentrated $\mathrm{H}_{2} \mathrm{SO}_{4}$ for the adsorption of pollutant from wastewater and the dibenzothiophene from fuel oils. Langmiur 19:731-736

Kadirvelu K, Kavipriya M, Karthika C, Radhika M, Vennilamani N, Pattabhi S (2003) Utilization of various agricultural wastes for activated carbon preparation and application for the removal of dyes and metal ions from aqueous solutions. Biores Technol $87: 129-132$

Kannan N, Sundaram MM (2001) Kinetics and mechanism of removal of methylene blue by adsorption on various carbons-a comparative study. Dyes Pigm 51:25-40

Karagoz S, Tay T, Ucar S, Erdem M (2008) Activated carbons from waste biomass by sulfuric acid activation and their use on methylene blue adsorption. Biores Technol 99:6214-6222

Khattri SD, Singh MK (1999) Colour removal from dye wastewater using sugar cane dust as an adsorbent. Adsorp Sci Technol 17:269-282

Lafi W (2001) Production of activated carbon from acrons and olive seed biomass. Biomass Bioenerg 20:57-62

Lagergren S (1898) Zur theorie der sogenannten adsorption geleoster Stoffe. Stockholm Kongl Svenska Vetenskaps-Akad Handlingar 24(4):1-39

Langmuir I (1916) The constitution and fundamental properties of solids and liquids. Part I. Solids. J Am Chem Soc 38:2221-2295

Luna MD, Flores ED, Genuino A, Futalan CM, Wan MW (2013) Adsorption of Eriochrome Black T (EBT) dye using activated carbon prepared from waste rice hulls-optimization, isotherm and kinetic studies. J Taiwan Inst Chem Eng 44:646-653

Maraghni M, Gorai M, Neffati M (2010) Seed germination at different temperatures and water stress levels and seedling emergence from different depths of ziziphus lotus. S Afr J Bot 76(3):453-459

Mattson JS, Mark HB (1971) Activated carbon. Dekker, New York

Pathania D, Sharma S, Singh P (2013) Removal of methylene blue by adsorption onto activated carbon developed from Ficus carica bast. Arab J Chem 3:55-62

Pavia DL, Lampman GM, Kaiz GS (1987) Introduction to spectroscopy: a guide for students of organic chemistry. W.B. Saunders Company, Philadelphia

Preethi S, Sivasamy A (2006) Removal of safranin basic dye from aqueous solutions by adsorption onto corncob activated carbon. Ind Eng Chem Res 45:7627-7632

Punzi M, Nilsson F, Anbalagan A, Svensson BM, Jönsson K, Mattiasson B, Jonstrup M (2015) Combined anaerobic-ozonation process for treatment of textile wastewater: removal of acute toxicity and mutagenicity. J Hazard Mater 292:52-60

Redlich O, Peterson DL (1959) A useful adsorption isotherm. J Phys Chem 63:1024-1026

Regti A, Tourit A, Laamari R, El Haddad M (2014) Enhancement removal of Basic Blue 9 dye from wastewaters using natural Moroccan wood as efficient adsorbent. Moroc J Chem 2:22-32

Rengarag S, Seung-Hyeon M, Sivabalan S, Arabindoo B, Murugesan V (2002) Agricultural solid waste for the removal of organics: adsorption of phenol from water and wastewater by palm seed coat activated carbon. Waste Manag 22:543-548

Ribas MC, Adebayo MA, Prola LD, Lima EC, Cataluña R, Feris LA, Puchana-Rosero MJ, Machado FM, Pavan FA (2014) Comparison of a homemade cocoa shell activated carbon with commercial activated carbon for the removal of reactive violet 5 dye from aqueous solutions. Chem Eng J 248:315-326

Rodrigues da Silva ME, Milen Firmino PI, Sousa MR, dos Santos AB (2012) Sequential anaerobic/aerobic treatment of dye-containing wastewaters: colour and COD removals, and ecotoxicity tests. Appl Biochem Biotechnol 166:1057-1069 
Rodriguez-Reinoso F, Molina-Sobia M, Gonzalez GC (2001) Preparation of activated carbon-sepiolite pellets. Carbon 39:77-785

Santhy K, Selvapathy P (2006) Removal of reactive dyes from wastewater by adsorption on coir pith activated carbon. Biores Technol 97:1329-1336

Shawabkeh R, Rockstraw D, Bhada R (1998) Activated carbon feedstock. United States Patent 6225256

Sulak MT, Demirbas E, Kobya M (2007) Removal of Astrazon Yellow 7GL from aqueous solutions by adsorption onto wheat bran. J Bioresour Technol 98:2590-2598
Tripathi M, Pandey MB, Jha RN, Pandey VB, Tripathi PN, Singh J (2001) Cyclopeptide alkaloids from Zizyphus jujuba. Fitoterapia 72(5):507-510

Yahya M, Al Qodah Z, Ngah CWZCW, Azman Hashim M (2015) Preparation and characterization of activated carbon from desiccated coconut residue by potassium hydroxide. Asian $\mathbf{J}$ Chem 27(6):2331-2336

Yu L, Luo Y (2014) The adsorption mechanism of anionic and cationic dyes by Jerusalem artichoke. J Environ Chem Eng 2:220-229 